\title{
Clinical Evaluations on the Diagnosis of Autism
}

\author{
Michaela Dobre ${ }^{1}$ and Ileana Stoica ${ }^{2}$ \\ 1"Lower Danube" University of Galati, Faculty of Medicine and Pharmacy \\ ${ }^{2}$ University of Bucharest, Faculty of Biology \\ Romania
}

\section{Introduction}

Autism spectrum disorders are currently formally diagnosed after pursuing two levels of investigation (Blackwell, 2001; Filipek et al., 1999, 2000). The first consists of monitoring the child's development and specific autism signal detection, which implies parent and physician attention, while the second involves actual diagnosis and evaluation, performed by specialized medical staff. Both levels of diagnosis rely on the careful observation of specific changes in child development, concerning movement, discovery and interaction with objects and people, games and language, which exhibit atypical variations in autism spectrum disorders. Intelligence tests, which aim to be a conventional estimate for the severity of mental retardation that may accompany autism, can serve as a relatively suitable approximation. There are many specific tests to diagnose autism, none ubiquously applied, and the final diagnosis depends on an overall estimation of brain function and, to a great extent, on the competence of the diagnostician. Therefore, the evaluation of a clinical diagnosis of autism through paraclinical methods - whether imaging, functional or laboratory work (metabolic, immunological, cytogenetic or molecular tests) - that would justify a medical conclusion, represents a necessity that is still unattainable. For autism spectrum disorders no specific paraclinical methods have as yet been identified, despite serious efforts invested. Traditional medicine was overcome in discriminate between different patients, thus opening the door for interdisciplinary studies which developed into new sciences, like psychoneuroendocrinology, psychoneuroimmunology and their corresponding insertions in genetics.

Over the years, some of the elements suspected to be involved in causing autism spectrum disorders were studied, providing mixed results. The present study will list converging results, and will attempt to portray autism from the perspective of modern investigation methods.

\section{Neuroimaging}

Imaging methods, from the classic X-ray to the CT-scan (computerized axial tomography), the PET (positron emission tomography), the SPECT (simple proton emission computerized tomography) and the MRI (magnetic resonance imaging), along with their functional variations - fMRI (functional Magnetic Resonance Imaging), sMRI (structural MRI), MEG (magnetoencephalography), DTI (diffusion-tensor tracking) - aim to highlight anatomical and physiological modifications in the central nervous system and associate them with autism spectrum disorders via physical or physiological parameter evaluations. 
Imaging is useful in diagnosing autism first of all by measuring brain component dimensions because in most autistic children, MRI studies showed a particular dynamics of brain and cranium development. Development peaks occur between 2 and 5 years of age, when cranial circumferences are above average and cerebral volume increases, and are followed, in adolescent and adult ages, by reduced cerebral dimension and function (Aylward et al., 2002; Courchesne et al., 2010; Hazlett et al., 2011). The evaluation and monitoring of child development dynamics may be performed using WHO Anthro software (World Health Organization-WHO, 2011), made in accordance with WHO standards (WHO, 2007) for children aged between 0 and 5 . For children above 5, statistical data is available from the Centers for Disease Control and Prevention - USA (Kuczmarski et al., 2002).

An in-depth and detailed analysis of the brain revealed some anomalies in component dimensions and especially in the ratio of white to grey matter: the corpus callosum is diminished (Frazier \& Hardan, 2009; Just et al., 2007); the frontal lobes are enlarged due to an excess of white matter (Cheng et al., 2010); the temporal lobes have a reduced grey matter content; the cerebellum has an over 30\% excess of white matter (Carper et al., 2002; Courchesne et al., 2010). Microscopical post-mortem imagery revealed Purkinje cell loss in the cerebellum. These particular cells are selectively vulnerable to hypoxia, ischemia, G-protein dysfunctions, viral infections, heavy metals, as well as to a wide range of metabolites and chemicals (Kern \& Jones, 2006). Histological studies also showed numerical reductions in amygdala axons (Schumann \& Amaral, 2006) and reduced cell sizes in the hippocampus, similar to what is seen in the case of a precocious maturation (Bauman \& Kemper, 2005). The two cerebral formations are involved in emotional and memory process development, two aspects typically targeted by autism spectrum disorders (Kleinhans et al., 2009; Saitoh et al., 2001). The use of MRI-DTI for the microstructural analysis of pathways interconnecting hippocampus and amygdala with the mid-fusiform gyrus in the temporal lobe (which participates in number, word, color and physiognomy recognition) revealed dysfunctionalities of these connections in autistic subjects which took a face recognition test (Conturo et al., 2008). The cause for this diminished response to stimuli was considered to be the reduction of axon diameters as a result of hypermielinisation, which yields a lower neuron conduction speed. Hippocampus and amygdala dimensions, which vary with the age and functionality of the investigated subjects, suggest the incongruence of cerebral components in the developmental dynamics.

A disharmonious development, a reduced corpus callosum volume and a small quantity of grey matter might justify the reduction in inter-hemispherical connectivity specific to autism (Hardan et al., 2009). Investigations using fMRI placed the causes for poor connectivity in the frontal insula, the superior temporal gyrus, the primary sensorimotor cortex, the lateral inferior premotor cortex and the superior parietal lobe (Anderson J.S. et al., 2010). The aforementioned areas are associated with social interaction management, social intelligence, new stimulus identification, sound processing and language linking, fine and gross motor activities, thereby encompassing all areas damaged by autism.

Specific modifications in verbal communication in autism spectrum disorders incriminate the reduced volume of grey matter in the Broca area (where the primary motor complex is responsible for talking motions in the left hemisphere), considering the fact that insufficient neural connectivity between the Wernicke and Broca areas lead to difficulties in lexical and semantic processing (Yamasaki et al., 2010). The comprehension and elaboration of language also depends, however, on auditory sensorial integration, which serves to perceive and analyze sound patterns. In the Knaus et al. study, linguistic scores were correlated with grey 
matter deficits found in frontal and temporal lobes, autistic subjects manifesting a typical lateralization of language (Knaus et al., 2010).

Temporal auditory associative areas, where mono- and multimodal auditory sensor integration crosses, are involved in the transfer of information to the internal structures of the limbic and frontoparietal integration systems. By measuring cerebral blood flow using high resolution PET as well as high resolution SPECT, the superior temporal region of the autistic child's brain was shown to have bilaterally localized hypoperfusions in the superior temporal gyrus and superior temporal sulcus, centered on the multimodal associative temporal cortex and auditory associative areas (Boddaert \& Zilbovicius, 2002; Ohnishi et al., 2000; Zilbovicius et al., 2000). This hypoperfusion was presumed to impair the transfer of auditory information and social perception (eye contact and facial expression), relational difficulties characteristic of autistic children. Ulterior studies, which undertook a neurofunctional perspective, reported diminished responses to auditory stimuli (Gomot et al., 2006) and visual stimuli (Bölte et al., 2008), along with hemodynamic modifications (Zilbovicius et al., 2006). The autistic brain reacts faintly to stimuli variations, a fact which agrees with some of the basic diagnosis criteria, such as a reduced interest for all surroundings, resistance to change and stereotypical activities.

Admitting that a diminished neural connectivity, due to an excess of white matter, and some cerebral area hypoperfusions are responsible for the functional afflictions specific to autism, it would be expected that a normalization of the blood flow would improve subject behavior. Positive developments as concerning hyperactivity, irritability, stereotyping as well as improvements in verbal communication were observed during prolonged periods of pathological fever, presumably responsible for an increased flow of blood to the cortex (Curran et al., 2007). Hyperbaric oxygen therapy (HBOT), as proposed by Rossignol (Rossignol \& Rossignol, 2006) also registered temporary improvements for autistic behavior (Chungpaibulpatana et al., 2008), oxygen supplementation techniques being well known also for their anti-inflammatory effects and their ability to regulate tissue perfusion and reduce oxidative stress.

Grey matter is not only present in reduced volume in the autistic brain, but also badly distributed, as it is found in a thin layer in cerebral areas associated with socialization and all that which it entails: audio-visual and olfactory stimuli processing, face recognition, imitation and language (Hadjikhani et al., 2006). This situation corresponds to the mirror neuron system, activated in the normal brain when observing and imitating an action, and also considered responsible for empathy and mentalization. The mirror neuron system is dysfunctional in autistic subjects, as enforced by fMRI, MEG and EEG findings (Dapretto et al., 2006; Oberman et al., 2005; Perkins et al., 2010).

Modern neuroimaging supports neuropsychological hypotheses concerning the causes of autism, i.e. the limbic system hypothesis, the weak central coherence hypothesis, the executive function hypothesis and the mentalization theory, but without being able to validate them (Bade-White et al., 2008; Joseph, 1999).

The limbic system, presumed responsible for memory deficits that negatively impact communication and social interaction, was associated through imaging with structural and functional changes especially in the hypothalamus and amygdala, known to be correlated with affective and emotional behavior, sense of smell and long term memory.

Weak central coherence, which implies a difficulty to integrate separately perceived elements into a whole, is associated with restricted interest and behaviour. Poor central 
coherence may be supported by a disproportion between white and grey matter and diminished neural connectivity but, considering the fact that the central coherence mechanism is postulated rather than demonstrated, imagistic information such as activity lateralization in the autistic brain and predominant involvement of the left hemisphere may be admitted as atypical, compensatory connections (Pierce et al., 2001).

The executive function hypothesis, which concerns intelligence and flexibility when establishing priorities, is associated with the prefrontal cortex and, especially, the dorsolateral areas. It has been proven that lesions in the aforementioned areas substantially impair executive functions, with imagistic evidence available (Levin \& Hanten, 2005). In the case of autism, executive dysfunction manifests in the absence of lesions and exhibits heterogeneous cortically distribution, associable with cyto-architectural defects and/or atypical connectivity (Gilbert et al., 2008).

To oppose the executive dysfunction and weak central coherence hypotheses, which aim to explain obsessive, repetitive autistic behavior as a blockage in information processing resulting from neuroanatomical and neurofunctional causes, Baron-Cohen et al. (BaronCohen et al, 2009) suggest repetitiveness as a consequence of hyper-systematization. This aspect, remarkable in gifted high-functioning autism, is associated with sensory hypersensitivity which favors an exceptional perception of visual, auditory and tactile details and may be due to a special type of informational processing, correlated with various neurotransmitters through modifications in receptor density and sensitivity or inhibition/stimulation mechanisms.

The mentalization theory concerns one's capacity to understand another's thoughts, engaging intention, visual contact and emotional communication. The existence of deficiencies in empathy and mentalization, associated with autism using psychological tests (Baron-Cohen, 1985), was endorsed by functional imaging, which revealed reduced activity in mirror neurons when recognizing a motor act preformed by another (Iacoboni \& Dapretto, 2006). Admitting that mentalization is more than imitation, the same imagistic tests performed when intentionality was separated from the motor act (why-use vs. whyplace), showed that autistic patients recognize the intention behind an action but can not anticipate the action using the motions that make it up (Boria et al., 2009). Therefore, mentalization theory can not be limited to the incrimination of mirror neurons, as these seem to be included into an extended cortical motor system (Rizzolatti \& Fabbri-Destro, 2010). Probable causes for this system's malfunctions are presumed to also be neural connectivity defects and white substance distribution.

Imaging, along with specific marker neurochemicals, helped detect areas activated by some cerebrally distributed hormones, impossible to dose in vivo. Thusly, in the presence of a marked substitute of tryptophane, PET revealed reduced serotonin activity in the thalamus and frontal cortex (Chugani et al., 1999). By analyzing active serotonin and dopamine transport in the high-functioning autistic brain through a combination of MRI and PET, a significant decrease in serotonin distribution volumes was noticed throughout the brain, along with a volume increase for dopamine, in the medial frontal area covering the orbitalfrontal complex (Nakamura et al., 2010). Serotonin deficiencies in the thalamus were in this case associated with repetitive/obsessive manifestations of autism.

MEG, another modern imagistic technique, proved to be much more sensitive, compared to EEG, in detecting forms of epilepsy, and contributed to the reevaluation of the frequency of these being associated with autism (Lewine et al., 1999). 


\section{Biomarkers}

Clinical laboratory tests aim to reveal measurable parameter variations in blood, urine, CSF or tissue samples, suggesting possibly altered metabolic processes in patients suffering from autism spectrum disorders.

Anemia, revealed by blood tests and iron and transferrin level assessments, support the hypothesis of cerebral tissue hypoxia and are frequently associated with autism spectrum disorders. It is believed that anemia has an irrevocably negative effect on intellectual function, especially when it occurs in pre-, peri- and postnatal life, even if hemoglobin levels subsequently normalize (Hurtado et al., 1999). Anemia tends to be chronic in autism spectrum disorders and is usually correlated with iron (Latif et al., 2002), folate (Moretti et al., 2005), and possibly ferritin (Dosman et al., 2007), transferrin and associated receptor deficiencies (Chauhan et al., 2004).

Common iron deficits may be due to insufficient food intake or absorption problems caused by the various gastrointestinal diseases that may accompany autism. A significant competitor to iron absorption from food is lead, classified as a neurotoxic environmental pollutant. Studies suggest that intoxication may occur even in pre- or postnatal periods, lead being delivered to the child through the mother's blood or milk (Gulson et al., 1998). Research has yet to accurately identify the origin of the lead or its role in autism spectrum disorders.

Iron deficits were also associated with non-alimentary consumption (pica), sometimes apparent in autism spectrum disorders (Barton et al., 2010).

Due to its ability to easily modify its oxidation state, iron participates in a large number of metabolic reactions, is included in hemoprotein structures and acts as an enzyme co-factor. As a component of hem, iron bound in hemoproteins takes part in vital metabolic reactions, such as oxygen transportation and storage (hemoglobin, mioglobin, neuroglobin), electron transfer in the respiratory chain and energy generation in the mitochondria (cytochromes $b$ and c) and is a component of catalases, peroxidases and hemothyolate proteins (NO synthetase, $\mathrm{P}_{450}$ proteins/cytochromes), which act to bind carbon monoxide, nitrogen monoxide and produce free radical oxygen. Qualitative or quantitative anomalies in these proteins, together with specific cognitive process impairments led to the hypothesis that metabolic causes may be behind autism, among these tissular hypoxia, mitochondrial function damage and oxidative stress.

Iron deficits associated with low hemoglobin levels explain the reduced levels of transported oxygen and plead for the cerebral hypo-oxygenation theory. However, there were cases when iron deficiencies accompany cognitive impairments without the presence of anemia, the cause of such occurrences being unknown (Hulthén, 2003). Recently discovered hemoprotein, neuroglobin, (Burmester et al., 2000), was attributed a neuroprotective role in cases of hypoxia and also a regulatory function for G-protein signaling systems (Wakasugi et al., 2005), but no related studies have yet been undertaken in autism spectrum disorders.

On the other hand, iron deficiencies do not only reflect low hemoglobin, iron being also well distributed in tissues. A recent study (Fukunaga et al., 2010), used immunofluorescence to prove that iron bound in ferritine and basic myelinic proteins is non-uniformly distributed between cortical layers, a fact that may be interpreted as the quality of contrast on MRI imagery. Iron deposits were frequently identified in collocation with myelin. Considering the predominantly lipoidic structure of the white matter, such positioning might suggest 
iron placement is opportune for insertion, via cytochrome $\mathrm{P}_{450}$, into the biosynthesis of cholesterol and other myelinic lipids that envelop the nervous fiber. Ferritin, in its two forms, $(\mathrm{H}$ and $\mathrm{L})$, its adequately placed receptors and its different expressions in microglia and oligodendrocytes (Sammarco et al., 2008) might play an as yet undeciphered part in myelin regularization, impaired in autism. Considering the excessive white matter synthesis in the early years of an autistic child's life and the frequency of anemia in the same period, Hay et al. (Hay et al., 2007) performed a study on normal children of the same age group in order to assess the quantity of transferring receptors. Receptor concentrations proved to vary, dropping in the first two years of life, but being higher in boys ever in intrauterine life, possibly as an influence of testosterone.

Excessive testosterone in the womb has also been incriminated, based on typical psychological differences between the sexes as a cause of autism, in what was called the "extreme male brain theory" forwarded by Baron-Cohen in 2002. This theory places autistic behavior in the male extremity of a human behavior curve built upon two criteria: systematization (as a mark of masculinity) and empathy (as a mark of femininity). In this theory, testosterone is the only hormone made responsible for sexual dimorphism. Excessive testosterone, infiltrated prenatally, has supposedly exacerbated systematic capabilities, as well as dramatically reduced empathy, thereby creating an extremely masculine individual. At the same time, increased levels of fetal testosterone may lead to more dramatic behavior alterations within the male population, thus justifying the predominance of autism in males (sex ratio 4:1). The validity of this theory is still to be demonstrated, with large scale future experiments aiming to clarify the role of fetal testosterone in the delimitation between normal and pathological psychoneurological development. The few studies hitherto carried out used radioimmunochemical methods to evaluate fetal testosterone in the amniotic fluid (Auyeung et al., 2009; Chura et al., 2010).

The "extreme male brain" theory is not the only one to place forward a hormonal cause to autism. More and more studies link autism-specific behavior alterations with levels of hormones derived from aminoacids (melatonin, serotonin, adrenalin/epinephrine, dopamine, noradrenalin/norepinephrine, GABA) or neuropeptides with hormonal activity (arginine vasopressin/ADH, oxytocin), making up the foundation of the hypothesis that autism is rooted in neuropsychoendocrinology.

Serum half-life for some hormones can be very low, so that measuring them in biological fluids is difficult and subject to operator bias.

Hormones derived from amino acids are biosynthesized by oxidizing enzymes with iron cofactors. Identifying hormonal deficiencies linked to altered psycho-social behavior in autism may also correlate with the low iron levels.

Tryptophane 5-monooxygenase (TPH) is part of the tryptophane metabolism enzyme chain and generates precursors for serotonin and melatonin. Serotonin, which occurs cerebrally as well as periferically (more than 95\%), is excreted as 5-hydroxy-indolil-acetic acid (5-HIAA). Serotonin concentrations may be measured directly or assessed by measuring its metabolite in spinal fluid or blood and urine, taking into account the fact that significant differences exist between periferical and cerebral media. Central serotonin deficiencies have been metabolically associated with autism using neuro-pharmacological methods. Prenatal stress induced by serotonin enhancing drugs, such as valproic acid, was associated with serotonergic neuron damage and is considered to be a potential cause of serotonin deficiencies in autism (Miyazaki et al., 2005). Low serotonin may explain the panic, anxiety, (auto)aggression as well as the repetitive/obsessive activities manifested in some forms of autistic behavior. 
Tyrozine-3-monooxigenase (TH) is involved in the synthesis of L-dihydroxyphenylalanin (L-DOPA), a precursor of dopamine and, consequently, of noradrenaline and adrenaline. Phenylalanine-4-monooxygenase (PAH) participates in the L-phenylalanine metabolism as a precursor of tyrosine and, consequently, chatecholamines.

Dopamine is a neuromediator stored in the hypothalamus, tightly linked to the central reward system, which associates certain actions with a sense of pleasure, and controls the actions necessary to fulfill the action. Through its responding to the novelty stimulus, dopamine is also involved in the learning by experience process. Levels of dopamine may be assessed by measuring the concentration of its metabolite, homovanilic acid (HVA). In some cases, autism was pharmacologically associated with elevated levels of dopamine, as its agonists actually accentuated stereotypical behavior and increased aggression, while dopamine antagonists produced slight alleviations of such behavior (Tsai, 1999).

From the perspective of hormonal activity, repetitive/stereotypical behavior may be regarded as an obstinate search for an unattained pleasure (lack of serotonin). However, the subject anticipates satisfaction and understands the motric details that should lead up to it, and therefore performs them repeatedly (high dopamine levels). This interpretation is consistent with the hyper-systemizing hypothesis, but may also explain short-term memory impairment which prevents learning and obtaining ultimate satisfaction from goal achievement.

The appliance of immunohistochemistry on animal brains lead to the observation that dopamine, as well as one of its receptors $\left(D_{1}\right)$, accentuates the development of GABA neurons, which play an important role in neuro-epithelial cell growth modulation, neuron migration and circuit forming (Crandall et al., 2007). The release of GABA in the synaptic space is equivalent to a cease of information transmission and depends on specific receptors, included in the neural membrane. One of these receptors $\left(\mathrm{GABA}_{\mathrm{A}}\right)$ is inhibited by zinc ions, located cerebrally using fluoro- and radiomarkers (Smart et al., 2004). When released into the synaptic space, zinc ions can block some post-synaptic glutamate receptors (NMDA type), thereby becoming a neuromodulator. Physiological zinc concentrations take on neuroprotective and anticonvulsive roles. In zinc deficiencies, excessive glutamate may lead to prolonged neural hyperexcitability, displayed through epileptic seizures (Takeda et al., 2003), often associated with autism spectrum disorders. Additionally, proton magnetic resonance imaging found elevated glutamate levels in the hippocampus and amygdala (Page et al., 2006). Zinc pools mainly in the hippocampus and amygdala, areas tightly linked to autism by imaging (Szewczyk et al., 2010).

GABA neurons are close to acetylcholine receptors, part of the cholinergic system, which coordinate autonomous functions using sympathetic and parasympathetic pathways. Upon stimulation of the acetylcholine receptor, the dopaminergic system was found to react by releasing GABA (Lester et al., 2010). Therefore, cognitive process alteration may reside in the dopaminergic system (neuroanatomical modifications, zinc metabolism, iron deficiencies) as well as in the cholinergic system (Youdim, 2008). This logic justifies autonomous function impairments that accompany autism, such as afflictions of the digestive tract (difficult nutritional uptake and swallowing, defective transit and vomiting), arrhythmias, fever episodes, altered pain perception, problems with urination, anxiety, emotional lability and impaired socialization.

Various numbers of studies were carried out on L-DOPA, adrenalin and noradrenalin and did not reveal significant correlations with autism. 
Low levels of melatonin link to frequent sleep abnormalities registered in autism (Melke et al., 2008). Melatonin uptake improves nightly sleep for autistic children as well as for other categories of people struggling with circadian rhythms. Circadian preferences may be associated with autistic hyper-sensitivity to auditory or other disruptive environmental stimuli, unnoticeable to normal people.

Neuropeptides involved in neural signaling, influence cerebral activity and are linked to complex processes such as learning and memory, essential to create personality and adaptability. Studies suggest arginine vasopressin and oxytocin may influence neural connections related to individuals relation forming therefore, recently come important for autism correlations.

Arginine vasopressin is synthesized in the hypothalamus, stored in the posterior hypophysis and released in the supraoptical nuclei according to the circadian rhythm. Oxytocin is secreted by the hypophysis and also acts remotely, like arginine vasopressin, its action modulated by receptors. Animal studies showed that hormonal action completion depends both on the concentration of neuropeptides and respective receptor density. In 1987, Le Moal and Dantzer carried out studies on mice to prove associative behavioral differences correlate with antidiuretic hormone levels. Excess arginine vasopressin was linked with associative relation stability, i.e. monogamy. Winslow et al. studies associated arginine vasopressin with male voice modulations in a social context, in some species of monkeys, and also with increases in motor activity upon central hormone administration (Winslow \& Insel 1991; Winslow et al., 1993). Increased levels of arginine vasopressin in the hypothalamus was recorded post-partum, in both males and females of certain rodent families, hinting to the hormone's role in affiliation, attachment and sexual and parental behavior manifestations (Wang et al., 2000). Increased levels of ADH found in human CSF and murine brains were correlated with aggression as well as with social memory. Autistic subjects showed increased levels of arginine vasopressin (Boso et al., 2007) and reduced levels of oxytocin (Modahl et al., 1998). Resulting anxiety was relieved by oxytocin nasal spray administration, which appeared to also contribute to an improvement in verbal and affective communication. Ferguson et al. hypothesized arginine vasopressin involvement in the consolidation (rather than acquisition) of social memory (Ferguson et al., 2002). All these studies revealed a more predominant influence of vasopressin in males, the equivalent of which being oxytocin in females (Lim \& Young, 2006). Protective behavior towards offspring and the pursuit of social integration ("tend-and-befriend") are linked to oxytocin and the female sex, while the male is attributed adaptive-aggressive ("fight-or-flight") behavior. Specific receptor distribution was found to be influenced by steroid sexual hormones and differentiated by sex and displayed level of affinitive behavior (Hammock et al., 2006). Some dopamine receptors are laminar distributed with oxytocin receptors, making their interaction more likely in social attachment behavior, while arginine vasopressin receptors are disfavored (Smeltzer et al., 2006).

The hypothetic hormonal cause to autism intersects with the oxidative stress hypothesis when it comes to glutamate exocytotoxicity. Glutamate release into the extracelluar space leads to increased intracytoplasmatic calcium ion levels but, when concentrations above $10^{-5}$ $\mathrm{M}$ are reached, calcium is pumped through membrane transport proteins into the interior of mitochondria (Krauss, 2003), where it triggers metabolism through matrix dehydrogenases. Besides contributing to ATP production, the shift of iron state of oxidation generates free radicals that are detoxified, in physiological conditions, by the mitochondrial antioxidation systems: superoxid dismutase, catalase, glutathione peroxidase, glutathione reductase - 
enzymes lacking in autism (Yorbik et al., 2002). Given time and non-physiological conditions, reactive oxygen species generated cause mitochondrial damage, decreased ATP production and, eventually, apoptosis. Considering the fact that apoptosis is integral to development, morphogenesis and homeostasis, as it removes excessive or irrecoverable cells from the cellular cycle arrest, it is admissible that endogenous and/or exogenous stress factors in prenatal, postnatal periods and early years influence cerebral architecture and development, vulnerable to oxidative stress.

Some substances, such as lactate, piruvate, aspartate, found in excess levels in blood and urine also plead for the hypothesis that mitochondrial functions may be impaired (Giulivi et al., 2010; Weissmann et al., 2008). Lactate, which appears in blood as a secondary product of anaerobic glycolysis, points to tissular hypoxia caused by mitochondrial oxidative phosphorilation impairment and, in association with anion gaps, may lead to metabolic acidosis, encountered in some cases of autism (Lombardi, 1998). In some patients, MRI and PET scans showed diminished rates of glucose metabolization in the striatum and thalamus (Haznedar et al., 2006). Lactatemia also registers as a side effect of anticonvulsive treatment, administered when autism is aggravated by epilepsy (Willmore et al., 2006).

Oxidative stress occurs when antioxidant capacity is overwhelmed, either because insufficient free radical scavenging enzymes are produced, because glutathione levels drop, or there are excessive reactive oxygen species (ROS) induced by exogenous factors (e.g. toxic heavy metals such as lead or mercury).

In antioxidant enzyme deficits, mitochondrial permeability transition increases in astrocytes for an endogenous toxic, difficult to annihilate: ammonia (Seyan et al., 2010). Excessive ammonia, found in some autistic subjects, represents the consequence of urea cycle defects (ornitin transcarbamilase/OTC, argininosuccinic acid/ASA syntethase deficiencies) or is a side-effect of anticonvulsive medication. Chauhan et al. (2004) associates oxidative stress in autism with low transferrin and plasmatic ceruloplasmin coupled with accentuated lipid peroxidation. Normal zinc levels would not allow excessive lipid peroxidation but, in autists, zinc levels were usually found to be low. Zinc deficiencies may also generate shortages of superoxide dismutase (a Cu-Zn enzyme).

Glutathione insufficiencies were revealed by HPLC in a study carried out on autistic subjects by James et al. and were associated (via homocystein) with decreased methyonin cycle turnover (James et al., 2004). This, in turn, implies a diminished synthesis of Sadenosyl methyonin (SAM), which is required to methylate proteins and DNA (Waterlow, 2006). The redox/methylation hypothesis (Deth et al., 2008), put forward as an expression of the response to environmental stress factors, is, as yet, insufficiently supported by ample genetic studies to investigate methylation profiles in autism and their roles in neural network synchronization.

The possibility exists that this scenario correlates with various types of anemia encountered in autism either through folate deficiencies (cysteine is obtained from homocysteine by means of a folate-dependent enzyme) or through the iron lost by high urinary porphyrin elimination, as a result of oxidative stress induced by heavy metal poisoning (Geier et al., 2009). Urinary porphyrin concentrations are comparable to those found in adults exposed to mercury poisoning, in which the presence of an atypical porphyrin in urine (precoproporphyrin) is associated with an inhibitory effect of mercury on kidney uroporphyrinogen decarboxilase (Woods et al., 2010). Since most investigated subjects did not have significant (organic/inorganic) mercury levels, the mechanism of this disturbance in the hemoglobin metabolism in autism is still unclear. 
Glutathione deficiencies also correlate with gastrointestinal dysfunctions that often accompany autism. Oxidative stress is emphasized upon intake of a large gamut of foods, while the intestinal wall opposes the passage of toxic agents into the body. The maintenance of high levels of antioxidants (glutathione, vitamin C, tocopherols) and also of antioxidant enzymes represents two cellular integrity defense mechanisms. Should these fail, the intestinal cell is directed towards apoptosis or necrosis. (Aw, 1999).

A preliminary response to oxidative stress is white cell proliferation and subsequent signal cascade, followed by neutrophyle infiltration into intestinal cells, through diapedesis. Cellular migration is associated with an increased synthesis of proinflammatory cytokines (e.g.: IL-1 $\beta$, IL-6, IL-8 and TNF- $\alpha$ ), which act as a "first response" in acute inflammatory reactions. Anti-inflammatory response is quick to appear, as evident through IL-4, IL-13 and TGF- $\beta$ cytokine synthesis. Ingesting food high in Maillard reaction final products activates macrophages and spreads intestinal inflammation to the entire organism (Georgescu, 2005; Muscat, 2007). Cytokines, as well as free radicals, activate the intranuclear translocation of the NF-kB transcription factor which, when bound to DNA, modulates numerous genes involved in inflammation and immunity. Intestinal mucose inflammation, histologically investigated through biopsies, was associated in autism with increased TNF-a, IL-2 and IL-4 in the duodenum and elevated TNF- $\alpha$ in the colon, with a more pronounced proinflammatory activity in subjects whose diets included casein and gluten (Ashwood et al., 2004). Proinflammatory (IL-1 $\beta$, IL-8 and especially TNF- $\alpha$ ) and anti-inflammatory (IL-4, IL-10, IL-12) cytokines, found in plasma, CSF, culture cells and in post-mortem cerebral tissue were found to be in high concentrations in autism (Ashwood et al., 2006; Chez et al., 2007). It is noteworthy that cytokines can cross the blood-brain barrier, affect neuron function and accentuate metabolism for hormones such as noradrenalin, dopamine and serotonin (Pickering et al., 2005; Zhao B. \& Schwartz, 1998). Some cytokines were associated with autism specific aspects such as sleep, cognitive function abnormalities or depression (IL-2, TNF-a) (Larson, 2002). Additionally, anti-cerebral peptide autoantibodies (antimyelin, antiPurkinje cells and anti-caudate nucleus) were identified by Western blots in serum, which speaks of a vulnerability of the blood brain barrier in autism (Singer et al., 2006). On the other hand, plasma harvested from autistic children's mothers was found to contain antibodies to human fetal brain of approximately $37 \mathrm{kD}$ and $73 \mathrm{kD}$, which may represent a possible contribution of the maternal immune system to autism etiology (Braunschweig et al, 2008). Since oxidative stress and/or immunological vulnerability is manifested in autistic children from a very early age, it is legitimate to suspect that these may be consequences of environmental conditions in the mother's womb (Dietert \& Dietert, 2008; Kinney et al, 2008).

\section{Genetic and molecular testing}

Any attempt to evaluate a diagnosis of autism can not escape genetic and molecular investigation. The heterogeneity of the psychological, morphological and functional aspects which contributed to the classification of the forms of autism undoubtedly has a genetic background that is currently being investigated, each organism being in fact an expression of its genetic pattern adapting to its environment. It is presumed that autism spectrum disorders have a major genetic component, with a complex and as yet undiscovered means of transmission. Twin studies revealed a rate of correlation of between 60 and $90 \%$ for monozygote twins and of 0 to $10 \%$ for dizygote twins (Bailey et al., 1995). 
It is unlikely, given the great diversity of symptoms and particularities of autism, that a single gene may mutate with pleiotropic effects. On the other hand, the same reasons make it very likely that the diverse manifestations may be due to environmental factors, which occur with various intensities and cause different responses, according to genetically dictated, individual tolerances. All things considered, autism is outlined as a complex manifestation, posing great difficulties when it comes to pinpointing its origins.

Identification of candidate genes was performed using methodology both direct and indirect (in the case of secondary autism, associated with other syndromes characterized by neuropsychiatric afflictions). The discovery of genes linked to Rett syndrome (MECP2), Joubert syndrome (AHI1), neurofibromatosis type 1 (NF1), tuberous sclerosis (TSC1) and fragile- $X$ syndrome (FMR1) allowed for differential diagnoses for these illnesses and opened the door to further genetic association for autism.

The direct approach to identifying the genetic components of autism used three categories of methods: chromosomal analysis, linkage and association studies and, respectively, candidate gene direct analysis. The numerous and various outcomes called for the development of specific databases. The Centre for Applied Genomics, established in 2004, in Toronto, maintains the Autism Chromosome Rearrangement Database, which comprises both cytogenetic as well as array comparative genomic hybridization/aCGH data. The Autism Genetic Database (AGD), established in 2009 at the University of Kansas, offers a generous list of autism-susceptible copy-number variations/CNVs (743) and genes (243), as well as a series of fragile sites (120) and non-coding RNA genes which act as regulators and are intensely expressed in the nervous system (more than 650.000) (Matuszek \& Talabizadeh, 2009). Also, the Stritch School of Medicine database from the Loyola University of Chicago, offers an eloquent mapping of candidate genes (238), CNVs, SNP polymorphisms and microinsertion/deletion sites linked to autism (Autism Candidate Gene Map (ACGMAP) Database).

Structural variations, recorded through cariotyping and SNP polymorphism analysis, are found in many chromosomal sites throughout the haploid genome: 1p, 1q, 2q, 3p, 3q, 4p, 4q, $5 p, 5 q, 6 q, 7 q, 8 q, 11 p, 12 p, 13 q, 15 q, 16 p, 17 q, 19 p, 19 q, X p$ şi Xq (Xu et al., 2004). The most frequent rearrangements appear in $2 p, 7 p$ (translocations in the $7 q 22-q 33$ regions), $15 q$ (duplications in the 15q11-q13 regions), 16p and X. Studies suggested that the modifications encountered are most often hereditary, but may also appear spontaneously - as previously documented or indeed, as novel forms - therefore demanding the taking into account of additional risk factors, whether genetic, epigenetic or environmental.

The loci that presented high CNVs comprise genes involved in neural development and synaptic activity, genes associated with oxidative processes, immunity or transcriptional processes, genes encoding various metabolic pathway enzymes, hormones and receptors, zones associated with mental retardation (15q24 and 16p11.2) as well as other genes with modified expressions. Locus 16p11.2 stood out with the highest CNVs frequency (1\%), correspondent to structural modifications that were mostly microdeletions and microduplications (Marshall et al., 2008; Weiss et al., 2008).

The most sought-after candidate genes were the ones most likely to be involved in central synaptic formation and modeling, cell adhesion and position and neural migration, such as: NLGN1 (3q26.31), NLGN3 (Xq13.1), X-linked NLGN4 (Xp22.32/33) and Y-linked NLGN4 (Yq11.221)/encoding for neuroligins, SHANK3 (22q13.3)/ankirin, PCDH9 (13q21.32)/protocadherin, NRXN1 (2p16.3), CNTNAP2 (7q35)/neurexins, RELN (7q22)/reelin (Glessner et al., 2009). 
After a study which looked at a great number of families with autism, Yonan et al. attribute significance to gene locus SLC6A4 (17q11.2) around the sequence exhibiting the maximum LOD score for 17q chromosome linkage (Yonan et al., 2003). The gene codifies a membrane protein for serotonin transport which carries the neurohormone from synaptic spaces into presynaptic neurons and which correlates with aggressive behavior and attention deficits. Deciphering the ever more important hormone contribution to psycho-behavioral modelling triggered a reorientation of studies towards genes encoding hormones, neuropeptides and membrane receptor cells like: GABRA3 (Xq28), GABRB3 (15q11.2-q12), GABBR2 (9q22.1q22.3)/encoding GABA receptor-proteins, which participate in the inhibition of excitation transmission, AVPR1A (12q14.2)/encoding the 1a arginine vasopressin receptor, OXT (20p13)/coding for oxytocin and neurophyzine 1, OXTR (3p25.3)/coding for oxytocin receptor, DRD1 and 3 (5q35 and 3q13.3)/coding for dopamine receptors (Anderson B.M. et al., 2008; Harony \& Wagner, 2010; Muhler et al., 2004; Yirmiya et al., 2006).

Some genes from autism linked-CNVs have metabolically correlated expressions, which amplify their candidate gene status. For example, 10 genes encode proteins from the phosphatidylinositol signal pathway and the glutamatergic synapse which are correlated through phosphatidylinositol-3-OH kinase (Cuscó et al., 2009). Genes like UBE3A (15q11.2), PARK2 (6q25.2-q27), RFWD2 (1q25.1-q25.2) and FBXO40 (3q13.33), which encode similar function proteins (ubiquitin protein ligases), are associated with ubiquitin degradation as well as neuron cell adhesion (Glessner et al., 2009). Also, the SLC6A4 gene, involved in serotonin metabolic and signal pathways, was associated, by epistasis, with the ITGB3 (17q21.32) gene, encoding an integrin (Coutinho et al., 2007). An interesting correlation was found in astrocytes, between a V1a arginine vasopressin receptor antagonist and the hormone's anti-inflammatory and immunomodulating activities, by suppressing gene expression for IL-1a, IL-1 $\beta$, IL-2 and TNF- $\alpha$ cytokines using a CREB transcription factordependant mechanism (Zhao L. \& Brinton, 2004). The CREB1 (2q34), along with SHANK3, DLG3 (Xq13.1) and DLG4 (17p13.1) genes, were also studied in association with memory and learning processes, afflicted by autism.

As deciphering genetic mechanisms is still a distant goal, suspicion falls, for the moment on genes like FOXP2 (7q31), involved, in embryogenesis, in the developing cerebral regions associated with language, CNTNAP2 (7q35-q36), encoding a neurexin-type protein or DYX1C1 (15q21.3), which gives susceptibility to dyslexia.

The contribution of these genes to autism remains disputed, as association frequencies are low. Without any firm links between identified genetic modifications and autism, more recent studies aimed to characterize polymorphisms in regulatory zones - an undertake made easier by the completion of human genome sequencing. Also, animal model studies additionally augment data acquisition. An eloquent example is the analysis of AVPR1A gene promoter polymorphisms: by observing affiliative behavior in mice, it was concluded that arginine vasopressin levels are not the only factors that influence affiliation, and that the distribution of membrane hormone receptors, encoded by the AVPR1A gene, also plays a part. The three polymorphisms identified in the gene promoter were presumed to influence gene expression and, in consequence, were associated with types of affiliative behavior. Considering the genetic similarities between mice and humans, these polymorphisms were studied in connection with autism, which exhibits a powerful alteration of affiliative impulses. Studies revealed a transmission imbalance of RS1 and RS3 polymorphisms linked to autism (Kim et al., 2002), associated with willing socialization (Yirmiya et al., 2006) and prepulse inhibition in auditory stimulus response as stress- 
adaptive reaction (Levin et al., 2009). Another pathway for research are the epigenetic studies, from among which global methylation profile investigation revealed significant modifications in two genes: RORA (15q22.2) and BCL-2 (18q21.3), whose expressions are subdued in the autistic brain (Nguyen et al., 2010). A recent study by Sarachana et al. stresses the importance of RORA as a candidate gene, because of the correlation between its expression and testosterone levels. RORA-encoded protein synthesis is stimulated by female hormones and inhibited by male ones. In the autistic brain, besides reduced RORA-protein levels, low aromatase levels were also found (Sarachana et al., 2011). Aromatase is an enzyme from the $\mathrm{P}_{450}$ cytochrome family which acts to maintain an elevated testosterone level. The molecular mechanism proposed by this study might explain the elevated frequency of autism among the male population and also add an argument to support Baron-Cohen's "extreme male brain" theory.

\section{Conclusion}

There is no concrete data on autism before Kanner (1943). For years, autism was considered a rare illness consisting of emotional contact impairments in children. As psychologists and psychiatrists looked more closely into the matter, autism was scrutinized, classified and linked with a triad of modified behavioral aspects involving socialization, language and obsessive/repetitive actions. During the last 30-odd years, the frequency of autism began to rise dramatically, up to alarming levels in some countries. Whatever the cause of this increase (better information dissemination among the medical community and the general population and/or a real increase in the number of afflicted children) autism was boosted to the peak of modern research interest and major resources were devoted to discovering the underlying causes of this developmental disorder.

The study of the brain, as the material basis for psychic processes, emerged as a prioritized research direction and the discovery of new means of imagistic investigation helped make a significant leap for normal and pathological cerebral anatomy and function understanding. Studies of the autistic brain converge to a general unitary conclusion of cerebral spatial and temporal development impairment. The defining elements for autistic anatomo-functional defects are excessive white substance and low neural connectivity, which may be linked to anomalous neuron migration, axon and synaptic development, neural impulse transmission. Although modifications were described in many areas of the brain, the most frequent associations lead to the corpus callosum, thalamus, amygdala and cerebellum. Considering the behavioral triad afflicted by autism, deficient socialization was linked to the orbitofrontal, anterior cingulate and posterior parietal cortexes, the fusiform and inferior frontal gyruses, the amygdala and mirror neurons, impaired communication was traced to the Broca area, the superior temporal sulcus, the thalamus and the basal ganglia, while repetitive behavior was found to be reflected in the orbitofrontal and anterior cingulated cortexes, the basal ganglia ant the thalamus. For temporal anomalies, it remains to be said if excessive brain dimensions recorded in the early years of life is caused by prolonged neurogenesis or glial cell overproduction, perhaps in conjunction with delayed neuron death (Verhoeven et al., 2010). Performing neuroimagistic investigation on children with idiopathic autism is difficult. Functional study subjects require a former period of introduction and accommodation and need to exhibit a certain degree of comprehension and participation, therefore unavoidably implying older test subjects, which are often cited as "high-functioning autists" or Asperger syndrome sufferers. Moreover, correlating 
functional imaging with psycho-behavioral studies concerning affection entails, even for normal individuals, a certain degree of imprecision derived from the multiple variables that concur in the momentary psychic status-quo. In order to obtain relevant results, all applied techniques require synchronization between the time that the brain responds to a stimulus and the time at which the response is recorded, a reason for using professional actors as a control group (Perreau-Linck et al., 2007). Therefore, neuroimagistic studies have not yet been able to tell "where" autism-specific structural and functional modifications occur in the brain, but are breaking new ground for general human brain exploration, cerebral stimulus processing and reactive response.

Another perspective for evaluating autistic diagnoses involves investigating biochemical and immunological profiles. This path is however subject to limitations imposed by the inherent differences between the presence and/or concentration of various substances in blood, CSF and brain tissue as a result of blood-brain barrier activity - while under suspicion that even this mechanism might be modified by autism. As access to brain tissue for biochemical or immunological studies is restricted and spinal punctures are invasive procedures to which parents seldom consent, the great majority of tests have to focus on blood or urine, in an attempt to identify products relevant for a diagnosis.

For patients diagnosed with autism spectrum disorders, laboratory testing indicated a series of very diverse blood or urine parameter alterations, which, even if associable with metabolic process dysfunctions, did not yield a stable marker for autism, but instead generated new plausible causalities materialized into theories based on the oxidative stress, mitochondrial, hormonal and neuro-transmission dysfunctions, signal pathway alterations, immune dysregulation, maternal-fetal effects or subsequent combinations thereof. Unfortunately, no complex study has yet to use a single large study lot with good representation for all types of autism in order to simultaneously check for biochemical and immunological anomalies otherwise fractionally identified (a metabolomic approach) such as: oxidative enzyme and glutathione deficiencies, metal poisoning, excess lactate and pyruvate, disturbances in the urea cycle, iron and zinc deficits, low levels of serotonin and melatonin, excessive dopamine, the arginine vasopressin/oxytocin balance, atypical porphyrins in urine or excessive pro- and anti-inflammatory cytokines. For the moment, test results show little uniformity, as the polymorphic and complex spectrum of autism demands a quasi-individual approach for each patient. Understanding the need for a systematic approach to autism, the National Institute of Health (USA) launched an ambitious attempt to create a national, interactive network (The Interactive Autism Network) to facilitate data flow. The National Database for Autism Research (NDAR), established in November 2010, also aids future studies by making available a wide database of reference imagery as well as autistic genotypes and phenotypes. It functions in close collaboration with the Autism Genetic Resource Exchange (AGRE), which offers DNA, cell lineages and serum from families with autistic children. The aforementioned institutions are also currently considering the future establishment of a brain tissue database.

While biochemical and immunological analysis can not definitively answer "what" causes autistic behavior or "how", neither can genetic testing indicate "who" is responsible for the modifications observed. Hundreds of studies sought associations between abnormal protein levels (structural proteins, enzymes, hormones, receptors, immunoproteins), their encoding genes and their corresponding regulatory regions. Results encountered the same inconsistencies regarding autism causality, but the amount of new data brought into behavioral genetics is by no means unimportant. New genomic analysis methods (aCGH) 
point to chromosomal areas most likely to be associated with autism, which reduce gene selection areas, admitting that their numbers may mean to autism either the contribution of more than one locus, genetic heterogeneity, epigenetic effects, or the result of environmental influence on genetic givens.

The evaluation of a diagnosis of autism has to arrive at answering "when?" and "how?" development impairment occurs on such a debilitating scale. Mental illnesses - therefore also autism - are regarded as multifactorial disorders. It is therefore plausible that an environmental factor, even in small quantities, is capable of setting in motion a series of molecular and cellular alterations which induce major behavioral modifications compatible with autism. It can be also inferred that this trigger for anatomical and functional brain damage penetrates the womb, where it may act upon the central nervous system throughout its long development, thus accounting for the permanence of the affliction. In order to reach the cerebral level, the presumed environmental factor, whether biological or chemical in origin, should be capable of crossing the open blood-brain barrier (while in uterus) or, if contamination occurs after the barrier has closed, to navigate it with or without inflicting structural changes. Some studies suggest that oxidative stress may affect blood brain barrier function (Lochhead et al., 2010) and others point to certain inefficiencies in the barrier itself in autism.

The fact that oxidative stress is capable of influencing gene expression by modifying DNA methylation patterns enforces the suspicion that it plays a critical role in autism. Oxidative stress on the organism is maintained by heavy metals, pesticides or Maillard reaction final products. These are brought into the body through aliments and may exert neurotoxic effects even in the womb, provoke redox imbalances, alter metabolic pathways, change membrane permeability or cause inflammation and immunological vulnerability. Perhaps it is not by chance that countries that use large quantities of organo-phosphate pesticides have the highest frequencies of autism, considering the fact that the enzyme that breaks down these products, paraoxonase 1, is deficient in autism (Deth et al., 2008; Paşca et al., 2006). Also, career-making women, who come to consume food that is nutritionally altered by packaging, coloring and flavoring, develop greater risks of delivering autistic children. Maillard reaction products intervene, among other things, in iron and zinc complexation (Zhang et al., 2009) - which may explain why these ions are scarce in autistic children, even before birth. On the other hand, from the hormonal perspective, whether modern women suffer from excessive testosterone and, furthermore, whether that can be linked to autism via the "extreme male brain" justification remains to be proven by further, more consistent, studies.

The effort to identify the cause behind autism spectrum disorders is coming more and more to resemble a worldwide, multifrontal assault on an impregnable labyrinthine territory. Current research implies an interdisciplinary approach to the complexity of the autistic phenomenon in order to arrive at relevant genotype-phenotype-environment correlations that offer a chance of early diagnosis and/or therapeutic approach.

\section{References}

Anderson, B. M., Schnetz-Boutaud, N., Bartlett, J., Wright, H. H., Abramson, R. K., Cuccaro, M. L., Gilbert, J. R., Pericak-Vance, M. A., \& Haines, J. L. (2008). Examination of association to autism of common genetic variationin genes related to dopamine. Autism Res, Vol. 1, No. 6, (December 2008), pp. 364-369, ISSN: 1939-3792 
Anderson, J. S., Druzgal, T. J., Froehlich, A., DuBray, M. B., Lange, N., Alexander, A. L., Abildskov, T., Nielsen, J. A., Cariello, A. N., Cooperrider, J. R., Bigler, E. D., \& Lainhart, J. E. (2010). Decreased Interhemispheric Functional Connectivity in Autism. Cerebral Cortex. Advance online publication. Accessed on February 7, 2011, Available from:

http://cercor.oxfordjournals.org/content/early/2010/10/12/ cercor.bhq190.long

Ashwood, P., Anthony, A., Torrente, F., \& Wakefield, A. J. (2004). Spontaneous Mucosal Lymphocyte Cytokine Profiles in Children with Autism and Gastrointestinal Symptoms: Mucosal Immune Activation and Reduced Counter Regulatory Interleukin-10. Journal of Clinical Immunology, Vol. 24, No. 6, (November 2004), pp. 664-673, ISSN: 0271-9142

Ashwood, P., Wills, S., \& Van de Water, J. (2006). The immune response in autism: a new frontier for autism research. Journal of Leukocyte Biology, Vol. 80, No. 1, (July 2006), pp. 1-15, ISSN: 0741-5400

Auyeung, B., Baron-Cohen, S., Ashwin, E., Knickmeyer, R., Taylor, K., \& Hackett, G. (2009). Fetal testosterone and autistic traits. British Journal of Psychology, Vol. 100, No 1, (February 2009), pp. 1-22, ISSN: 2044-8295

Aw, T. Y. (1999). Molecular and cellular responses to oxidative stress and changes in oxidation-reduction imbalance in the intestine. Am J Clinl Nutr, Vol. 70, No. 4, (October 1999), pp. 557-565, ISSN: 0002-9165

Aylward, E. H., Minshew, N. J., Field, K., Sparks, B. F., \& Singh, N. (2002). Effects of age on brain volume and head circumference in autism. Neurology, Vol. 59, No.2, (July 2002), pp. 175-183, ISSN: 0028-3878

Bade-White, P. A., Obrzut, J. E., \& Randall, P. P. (2008). Neuropsychological Aspects of Pervasive Development and Autism Spectrum Disorders, In: Handbook of Clinical Child Neuropsychology, 3-rd Ed., Reynolds, C.R. \& Fletcher-Janzen, E., pp. 765-783, Springer-Verlag, ISBN: 0387707085, New York, LLC

Bailey, A., Le Couteur, A., Gottesman, I., Bolton, P., Simonoff, E., Yuzda, E., \& Rutter, M. (1995). Autism as a strongly genetic disorder: evidence from a British twin study. Psychological Medicine, Vol. 25, No. 01, (January 1995), pp. 63-77, ISSN: 0033-2917

Baron-Cohen, S., Leslie, A. M., \& Frith, U. (1985). Does the autistic child have a "theory of mind"?. Cognition, Vol. 21, No. 1, (October 1985), pp. 37-46, ISSN: 0010-0277

Baron-Cohen, S. (2002). The extreme male brain theory of autism. Trends Cogn Sci. Vol. 6, No. 6, (June 2002), pp. 248-254. ISSN: 1364-6613

Baron-Cohen, S., Ashwin, E., Ashwin, C., Tavassoli, T., \& Chakrabarti, B. (2009). Talent in autism: hyper-systemizing, hyper-attention to detail and sensory hypersensitivity. Philos Trans R Soc Lond B Biol Sci, Vol. 364, No. 1522, (May 2009), pp. 1377-1383, ISSN: 1471-2970

Barton, J., Barton, J. C., \& Bertoli, L. (2010). Pica associated with iron deficiency or depletion: clinical and laboratory correlates in 262 non-pregnant adult outpatients. BMC Blood Disorders, Vol.10, No. 1, (December 2010), pp. 9, ISSN: 1471-2326

Bauman, M. L., \& Kemper, T. L. (2005). Neuroanatomic observations of the brain in autism: A review and future directions. Int J Dev Neurosc, Vol. 23, No. 2-3, (April-May 2005), pp. 183-187, ISSN: 0736-5748

Blackwell, J. (2001). Clinical practice guideline: screening and diagnosing autism, J Am Acad Nurs Pract, Vol. 13, No. 12, ( December 2001), pp. 534-6, ISSN: 1041-2972 
Boddaert, N., \& Zilbovicius, M. (2002). Functional neuroimaging and childhood autism, Pediatr Radiol, Vol.32, No.1, (January 2002), pp. 1-7, ISSN: 0301-0449

Bölte, S., Hubl, D., Dierks, T., Holtmann, M., \& Poustka, F. (2008). An fMRI-study of locally oriented perception in autism: altered early visual processing of the block design test. J Neural Transm, Vol 115, No.3, (February 2008), pp. 545-552. ISSN: 0300-9564.

Boria, S., Fabbri-Destro, M., Cattaneo, L., Sparaci, L., Sinigaglia, C., Santelli, E., Cossu, G., \& Rizzolatti, G. (2009). Intention understanding in autism. PLoS One. Vol. 4, No. 5, (May 2009), e5596. eISSN: 1932-6203. doi:10.1371/journal.pone.0005596

Boso, M., Emanuele, E., Politi, P., Pace, A., Arra, M., Ucelli di Nemi, S., \& Barale, F. (2007). Reduced Plasma Apelin Levels in Patients with Autistic Spectrum Disorder. Arch Medl Res, Vol. 38, No. 1, (January 2007), pp. 70-74, ISSN: 0188-4409

Braunschweig, D., Ashwood, P., Krakowiak, P., Hertz-Picciotto, I., Hansen, R., Croen, L. A., Pessah, I. N., \& Van de Water, J. (2008). Autism: Maternally derived antibodies specific for fetal brain proteins. Neurotoxicology, Vo. 29, No. 2, (March 2008), pp. 226-231, ISSN: 0161-813X

Burmester, T., Weich, B., Reinhardt, S., \& Hankeln, T. (2000). A vertebrate globin expressed in the brain. Nature, Vol. 407, No. 6803, (September 2000), pp. 520-523, ISSN: 00280836

Carper, R. A., Moses, P., Tigue, Z. D., \& Courchesne, E. (2002). Cerebral lobes in autism: early hyperplasia and abnormal age effects. Neuroimage, Vol. 16, No.4, (August 2002), pp. 1038-1051. ISSN: 1053-8119

Chauhan, A., Chauhan, V., Brown, W. T., \& Cohen, I. (2004). Oxidative stress in autism: increased lipid peroxidation and reduced serum levels of ceruloplasmin and transferrin--the antioxidant proteins. Life Sci, Vol. 75, No. 21, (October 2004), pp. 2539-2549, ISSN: 0024-3205

Cheng, Y., Chou, K. H., Chen, I. Y., Fan, Y. T., Decety, J., \& Lin, C. P. (2010). Atypical development of white matter microstructure in adolescents with autism spectrum disorders. Neuroimage, Vol 50, No.3, (April 2010), pp. 873-882, ISSN: 1053-8119

Chez, M. G., Dowling, T., Patel, P. B., Khanna, P., \& Kominsky, M. (2007). Elevation of Tumor Necrosis Factor-Alpha in Cerebrospinal Fluid of Autistic Children. Pediatric neurology, Vol. 36, No. 6, (June 2007), pp. 361-365, ISSN: 0887-8994

Chugani, D. C., Muzik, O., Behen, M., Rothermel, R., Janisse, J. J., Lee, J., \& Chugani, H. T. (1999). Developmental changes in brain serotonin synthesis capacity in autistic and nonautistic children. Ann Neurol, Vol. 45, No. 3, (March 1999), pp. 287-95, ISSN: 0364-5134

Chungpaibulpatana, J., Sumpatanarax, T., Thadakul, N., Chantharatreerat, C., Konkaew, M., \& Aroonlimsawas, M. (2008). Hyperbaric oxygen therapy in Thai autistic children. J Med Assoc Thai., Vol. 91, No. 8, (August 2008), pp. 1232-8, ISSN: 0125-2208

Chura, L. R., Lombardo, M. V., Ashwin, E., Auyeung, B., Chakrabarti, B., Bullmore, E. T., \& Baron-Cohen, S. (2010). Organizational effects of fetal testosterone on human corpus callosum size and asymmetry. Psychoneuroendocrinology, Vol. 35, No. 1, (January 2010), pp. 122-132, ISSN: 0306-4530

Conturo, T. E., Williams, D. L., Smith, C. D., Gultepe, E., Akbudak, E., \& Minshew, N. J. (2008). Neuronal fiber pathway abnormalities in autism: an initial MRI diffusion tensor tracking study of hippocampo-fusiform and amygdalo-fusiform pathways. $J$ Int Neuropsychol Soc., Vol. 14, No. 6, (November 2008), pp. 933-46, ISSN: 1355-6177 
Courchesne, E., Campbell, K., \& Solso, S. (2010). Brain growth across the life span in autism: Age-specific changes in anatomical pathology. Brain Res., Vol. In Press, Corrected Proof, (Oct, 2010), ISSN 0006-8993, doi:10.1016/j.brainres.2010.09.101 Article in Press.

Coutinho, A., Sousa, I., Martins, M., Correia, C., Morgadinho, T., Bento, C., Marques, C., Ataíde, A., Miguel, T., Moore, J., Oliveira, G., \& Vicente, A. (2007). Evidence for epistasis between SLC6A4 and ITGB3 in autism etiology and in the determination of platelet serotonin levels. Hum Genet, Vol. 121, No. 2, (April 2007), pp. 243-256, ISSN: 0340-6717

Crandall, J. E., McCarthy, D. M., Araki, K. Y., Sims, J. R., Ren, J.-Q., \& Bhide, P. G. (2007). Dopamine Receptor Activation Modulates GABA Neuron Migration from the Basal Forebrain to the Cerebral Cortex. J. Neurosci., Vol. 27, No. 14, (April 2007), pp. 38133822, ISSN: 0270-6474

Curran, L. K., Newschaffer, C. J., Lee, L. C., Crawford, S. O., Johnston, M. V., \& Zimmerman, A. W. (2007). Behaviors associated with fever in children with autism spectrum disorders. Pediatrics, Vol. 120, No. 6, (December 2007), pp. 1386-1392, ISSN: 10984275

Cuscó, I., Medrano, A., Gener, B., Vilardell, M., Gallastegui, F., Villa, O., González, E., Rodriguez-Santiago, B., Vilella, E., Del Campo, M., \& Pérez-Jurado, L. A. (2009). Autism-specific copy number variants further implicate the phosphatidylinositol signaling pathway and the glutamatergic synapse in the etiology of the disorder. Hum Mol Genet, Vol. 18, No. 10, (February 2009), pp. 1795-1804, ISSN: 0964-6906

Dapretto, M., Davies, M. S., Pfeifer, J. H., Scott, A. A., Sigman, M., Bookheimer, S. Y., \& Iacoboni, M. (2006). Understanding emotions in others: mirror neuron dysfunction in children with autism spectrum disorders. Nat Neurosci., Vol. 9, No. 1, (January 2006), pp. 28-31, ISSN: 1097-6256

Deth, R., Muratore, C., Benzecry, J., Power-Charnitsky, V. A., \& Waly, M. (2008). How environmental and genetic factors combine to cause autism: A redox/methylation hypothesis. Neurotoxicology, Vol. 29, No. 1, (January 2008), pp. 190-201, ISSN: 0161$813 X$

Dietert, R. R., \& Dietert, J. M. (2008). Potential for early-life immune insult including developmental immunotoxicity in autism and autism spectrum disorders: focus on critical windows of immune vulnerability. J Toxicol Environ Health B Crit Rev, Vol. 11, No. 8, (October 2008), pp. 660-680, ISSN: 1521-6950

Dosman, C. F., Brian, J. A., Drmic, I. E., Senthilselvan, A., Harford, M. M., Smith, R. W., Sharieff, W., Zlotkin, S. H., Moldofsky, H., \& Roberts, S. W. (2007). Children with autism: effect of iron supplementation on sleep and ferritin. Pediatr Neurol, Vol 36, No. 3, (March 2007), pp. 152-158, ISSN: 0887-8994

Ferguson, J. N., Young, L. J., \& Insel, T. R. (2002). The Neuroendocrine Basis of Social Recognition. Front Neuroendocrinol, Vol. 23, No. 2, (April 2002), pp. 200-224, ISSN: 0091-3022

Filipek, P. A., Accardo, P. J., Ashwal, S., Baranek, G. T., Cook, E. H. Jr., Dawson, G., Gordon, B., Gravel, J. S., Johnson, C. P., Kallen, R. J., Levy, S. E., Minshew, N. J., Ozonoff, S., Prizant, B. M., Rapin, I., Rogers, S. J., Stone, W. L., Teplin, S. W., Tuchman, R. F., \& Volkmar, F. R. (2000). Practice parameter: screening and diagnosis of autism: report of the Quality Standards Subcommittee of the American Academy of Neurology 
and the Child Neurology Society. Neurology, Vol. 55, No. 4, (August 2000), pp. 46879, ISSN: 0028-3878

Frazier, T. W., \& Hardan, A. Y. (2009). A meta-analysis of the corpus callosum in autism. Biol Psychiatry, Vol. 66, No. 10, (November 2009), pp. 935-941. ISSN: 1873-2402.

Fukunaga, M., Li, T-Q., van Gelderen, P., de Zwart, J. A., Shmueli, K., Yao, B., Lee, J., Maric, D., Aronova, M. A., Zhang, G., Leapman, R. D., Schenck, J. F., Hellmut Merkle, H., \& Duyn, J. H. (2010). Layer-specific variation of iron content in cerebral cortex as a source of MRI contrast. PNAS, Vol. 107, No. 8, (February 23), pp. 3834-3839, ISSN: 0027-8424

Geier, D. A., Kern, J. K., Garver, C. R., Adams, J. B., Audhya, T., Nataf, R., \& Geier, M. R. (2009). Biomarkers of environmental toxicity and susceptibility in autism. J Neurol Sci, Vol. 280, No. 1-2, (May 2009), pp. 101-108, ISSN: 1878-5883

Georgescu, L. P. (2005). Reacția de degradare oxidativă şi radicalică, In: Inhibarea degradărilor radicalice din sisteme model cu utilizarea substanțelor naturale, Georgescu P. Lucian, pp. 9-57, Editura Fundației Universitare “Dunărea de Jos” din Galați, ISBN: 973-627242-7, Galați.

Gilbert, S. J., Bird, G., Brindley, R., Frith, C. D., \& Burgess, P. W. (2008). Atypical recruitment of medial prefrontal cortex in autism spectrum disorders: an fMRI study of two executive function tasks. Neuropsychologia. Vol. 46, No. 9, (April 2008), pp. 2281-91, ISSN: 0028-3932

Giulivi, C., Zhang, Y.-F., Omanska-Klusek, A., Ross-Inta, C., Wong, S., Hertz-Picciotto, I., Tassone, F., \& Pessah, I. N. (2010). Mitochondrial Dysfunction in Autism. JAMA, Vol. 304, No. 21, (December 2010), pp. 2389-2396, ISSN: 00987484

Glessner, J. T., Wang, K., Cai, G., Korvatska, O., Kim, C. E., Wood, S., Zhang, H., Estes, A., Brune, C. W., Bradfield, J. P., Imielinski, M., Frackelton, E. C., Reichert, J., Crawford, E. L., Munson, J., Sleiman, P. M. A., Chiavacci, R., Annaiah, K., Thomas, K., Hou, C., Glaberson, W., Flory, J., Otieno, F., Garris, M., Soorya, L., Klei, L., Piven, J., Meyer, K. J., Anagnostou, E., Sakurai, T., Game, R. M., Rudd, D. S., Zurawiecki, D., McDougle, C. J., Davis, L. K., Miller, J., Posey, D. J., Michaels, S., Kolevzon, A., Silverman, J. M., Bernier, R., Levy, S. E., Schultz, R. T., Dawson, G., Owley, T., McMahon, W. M., Wassink, T. H., Sweeney, J. A., Nurnberger, J. I., Coon, H., Sutcliffe, J. S., Minshew, N. J., Grant, S. F. A., Bucan, M., Cook, E. H., Buxbaum, J. D., Devlin, B., Schellenberg, G. D., \& Hakonarson, H. (2009). Autism genome-wide copy number variation reveals ubiquitin and neuronal genes. Nature, Vol. 459, No. 7246, (February 2009), pp. 569-573, ISSN: 0028-0836

Gomot, M., Bernard, F. A., Davis, M. H., Belmonte, M. K., Ashwin, C., Bullmore, E. T., \& Baron-Cohen S. (2006). Change detection in children with autism: An auditory event-related fMRI study, NeuroImage, Vol.29, No.2, (January 2006), pp. 475-484, ISSN: 1095-9572.

Gulson, B. L., Jameson, C. W., Mahaffey, K. R., Mizon, K. J., Patison, N., Law, A. J., Korsch, M. J., \& Salter, M. A. (1998). Relationships of lead in breast milk to lead in blood, urine, and diet of the infant and mother. Environ Health Perspect. Vol. 106, No. 10, (October 1998), pp. 667-74, ISSN: 0091-6765

Hadjikhani, N., Joseph, R. M., Snyder, J., \& Tager-Flusberg, H. (2006). Anatomical Differences in the Mirror Neuron System and Social Cognition Network in Autism. Cerebral Cortex, Vol. 16, No. 9, (September 2006), pp. 1276-1282, ISSN:1047-3211 
Hammock, E. A. D., \& Young, L. J. (2006). Oxytocin, vasopressin and pair bonding: implications for autism. Philos Trans R Soc Lond B Biol Sci, Vol. 361, No. 1476, (December 2006), pp. 2187-2198, ISSN: 0962-8436

Hardan, A. Y., Pabalan, M., Gupta, N., Bansal, R., Melhem, N. M., Fedorov, S., Keshavan, M. S., \& Minshew, N. J. (2009). Corpus Callosum Volume in Children with Autism. Psychiatry Res., Vol. 174, No. 1, (October 2009), pp. 57-61. ISSN: 0925-4927

Harony, H., \& Wagner, S. (2010). The contribution of oxytocin and vasopressin to Mammalian social behavior: potential role in autism spectrum disorder. Neurosignals, Vol. 18, No. 2, (February 2011), pp. 82-97, ISSN: 1424-862X

Hay, G., Refsum, H., Whitelaw, A., Melbye, E. L., Haug, E., \& Borch-Iohnsen, B. (2007). Predictors of serum ferritin and serum soluble transferrin receptor in newborns and their associations with iron status during the first 2 y of life. Am J Clin Nutr. 2007 Jul; Vol. 86, No. 1, (July 2007), pp. 64-73, ISSN: 0002-9165

Hazlett, H. C., Poe, M. D., Gerig, G., Styner, M., Chappell, C., Smith, R. G., Vachet, C., \& Piven, J. (2011). Early brain overgrowth in autism associated with an increase in cortical surface area before age 2 years. Arch Gen Psychiatry, Vol. 68, No. 5, (May 2011), p. 467-476, ISSN:1538-3636

Haznedar, M. M., Buchsbaum, M. S., Hazlett, E. A., LiCalzi, E. M., Cartwright, C., \& Hollander, E. (2006). Volumetric analysis and three-dimensional glucose metabolic mapping of the striatum and thalamus in patients with autism spectrum disorders. Am J Psychiatry, Vol. 163, No. 7, (July 2006), pp. 1252-1263, ISSN: 0002-953X

Hulthén, L. (2003). Iron deficiency and cognition. Scan J Nutr, Vol. 47, No. 3, (September 2003), pp. 152-156, ISSN: 1102-6480

Hurtado E. K., Claussen A. H., \& Scott K. G. (1999). Early childhood anemia and mild or moderate mental retardation. Am J Clin Nutr, Vol 69, No. 1, (January 1999), pp. 1159, ISSN: 0002-9165

Iacoboni, M., \& Dapretto, M. (2006). The mirror neuron system and the consequences of its dysfunction. Nat Rev Neurosci Vol. 7, No. 12, (December 2006), pp. 942-951, ISSN: 1471-003X

James, S. J., Cutler, P., Melnyk, S., Jernigan, S., Janak, L., Gaylor, D. W., \& Neubrander, J. A. (2004). Metabolic biomarkers of increased oxidative stress and impaired methylation capacity in children with autism. Am J of Clin Nutr, Vol. 80, No. 6, (December 2004), pp. 1611-1617, ISSN: 0002-9165

Joseph, R. M. (1999). Neuropsychological Frameworks for Understanding Autism. Int Rev Psychiatry, Vol. 11, No. 4, (November 1999), pp. 309-324, ISSN: 0954-0261

Just, M. A., Cherkassky, V. L., Keller, T. A., Kana R. K., \& Minshew N. J. (2007). Functional and Anatomical Cortical Underconnectivity in Autism: Evidence from an fMRI Study of an Executive Function Task and Corpus Callosum Morphometry. Cereb. Cortex 17 (4): 951-961. ISSN: 1047-3211.

Kern, J. K., \& Jones, A.M. (2006). Evidence of toxicity, oxidative stress, and neuronal insult in autism. J Toxicol Environ Health B Crit Rev, Vol. 9, No. 6, (June 2006), pp. 485-499, ISSN: 1093-7404

Kim, S. J., Young, L. J., Gonen, D., Veenstra-VanderWeele, J., Courchesne, R., Courchesne, E., Lord, C., Leventhal, B. L., Cook, E. H., Jr., \& Insel, T. R. (2002). Transmission disequilibrium testing of arginine vasopressin receptor 1A (AVPR1A) 
polymorphisms in autism. Mol Psychiatry, Vol. 7, No. 5, (June 2002), pp. 503-507, ISSN: 1359-4184

Kinney, D. K., Munir, K. M., Crowley, D. J., \& Miller, A. M. (2008). Prenatal stress and risk for autism. Neurosci Biobehav Rev, Vol. 32, No. 8, (October 2008), pp. 1519-1532, ISSN: 0149-7634

Kleinhans, N. M., Johnson, L. C., Richards, T., Mahurin, R., Greenson, J., Dawson, G., \& Aylward, E. (2009). Reduced neural habituation in the amygdala and social impairments in autism spectrum disorders. Am J Psychiatry, 166(4), 467-475. ISSN: 1535-7228.

Knaus, T. A., Silver, A. M., Kennedy, M., Lindgren, K. A., Dominick, K. C., Siegel, J., \& Tager-Flusberg, H. (2010). Language laterality in autism spectrum disorder and typical controls: a functional, volumetric, and diffusion tensor MRI study. Brain Lang, Vol. 112, No. 2, (February 2010), pp. 113-120, ISSN: 0093-934X

Krauss, G. (2003). Intracellular Messenger Substances: "Second Messengers", In Biochemistry of Signal Transduction and Regulation. 3rd Edition. Gerhard Krauss, pp. 245-6, WILEY-VCH Verlag GmbH \& Co. KGaA, ISBN: 3-527-30591-2, Weinheim

Kuczmarski, R. J., Ogden, C. L., Guo, S. S., Grummer-Strawn, L. M., Flegal, K. M., Mei, Z., Wei, R., Curtin, L. R., Roche, A. F., \& Johnson, C. L. (2002). 2000 CDC growth charts for the United States: Methods and development. Vital Health Stat, Series 11, No. 246, (May 2002), pp. 39-40, ISBN 0-8406-0575-7

Larson, S. J. (2002). Behavioral and motivational effects of immune-system activation. J. Gen. Psychol. Vol. 129, No. 4, (October 2002), pp. 401-14, ISSN: 0022-1309

Latif, A., Heinz, P., \& Cook, R. (2002). Iron deficiency in autism and Asperger syndrome. Autism, Vol. 6, No. 1, (March 2002), pp. 103-114, ISSN: 1362-3613

Lester, D. B., Rogers, T. D., \& Blaha, C. D. (2010). Acetylcholine-Dopamine Interactions in the Pathophysiology and Treatment of CNS Disorders. CNS Neuroscience $\mathcal{E}$ Therapeutics, Vol. 16, No. 3, (June 2010), pp. 137-162, ISSN: 1755-5930

Levin, H. S., \& Hanten, G. (2005). Executive Functions After Traumatic Brain Injury in Children. Pediatric Neurology, Vol. 33, No. 2, (August 2005), pp. 79-93, ISSN: 08878994

Levin, R., Heresco-Levy, U., Bachner-Melman, R., Israel, S., Shalev, I., \& Ebstein, R.P. (2009). Association between arginine vasopressin 1a receptor (AVPR1a) promoter region polymorphisms and prepulse inhibition. Psychoneuroendocrinology, Vol. 34, No. 6, (July 2009), pp. 901-908, ISSN: 0306-4530

Lewine, J. D., Andrews, R., Chez, M., Patil, A. A., Devinsky, O., Smith, M., Kanner, A., Davis, J. T., Funke, M., Jones, G., Chong, B., Provencal, S., Weisend, M., Lee, R. R., \& Orrison, W. W., Jr. (1999). Magnetoencephalographic patterns of epileptiform activity in children with regressive autism spectrum disorders. Pediatrics, Vol. 104, No. 3 Pt 1, (September 1999), pp. 405-418, ISSN: 0031-4005

Lim, M. M., \& Young, L. J. (2006). Neuropeptidergic regulation of affiliative behavior and social bonding in animals. Hormones and Behavior, Vol. 50, No. 4, (November 2006), pp. 506-517, ISSN: 0018-506X

Lochhead, J. J., McCaffrey, G., Quigley, C. E., Finch, J., DeMarco, K. M., Nametz, N., \& Davis, T.P. (2010). Oxidative stress increases blood-brain barrier permeability and induces alterations in occludin during hypoxia-reoxygenation. J Cereb Blood Flow Metab, Vol. 30, No. 9, (September 2010), pp. 1625-1636, ISSN: 0271-678X 
Lombard, J. (1998). Autism: a mitochondrial disorder? Med Hypotheses, Vol. 50, No. 6, (June 1998), pp. 497-500, ISSN: 0306-9877

Marshall, C. R., Noor, A., Vincent, J. B., Lionel, A. C., Feuk, L., Skaug, J., Shago, M., Moessner, R., Pinto, D., Ren, Y., Thiruvahindrapduram, B., Fiebig, A., Schreiber, S., Friedman, J., Ketelaars, C. E. J., Vos, Y. J., Ficicioglu, C., Kirkpatrick, S., Nicolson, R., Sloman, L., Summers, A., Gibbons, C. A., Teebi, A., Chitayat, D., Weksberg, R., Thompson, A., Vardy, C., Crosbie, V., Luscombe, S., Baatjes, R., Zwaigenbaum, L., Roberts, W., Fernandez, B., Szatmari, P., \& Scherer, S. W. (2008). Structural Variation of Chromosomes in Autism Spectrum Disorder. American journal of human genetics, Vol. 82, No. 2, (February 2008), pp. 477-488, ISSN: 0002-9297

Matuszek, G., \& Talabizadeh Z. (2009). Autism Genetic Database: A comprehensive database for autism susceptibility gene-CNVs integrated with known noncoding RNAs and fragile sites. BMC Medical Genetics., Vol. 10, No. 1, (September 2009), pp. 102, ISSN: 1471-2350

Melke, J., Botros, H. G., \& Chaste, P. (2008). Abnormal melatonin synthesis in autism spectrum disorders. Mol Psychiatry, Vol. 13, No. 1, (January 2008), pp. 90-8, ISSN: 1359-4184.

Miyazaki, K., Narita, N., \& Narita, M. (2005). Maternal administration of thalidomide or valproic acid causes abnormal serotonergic neurons in the offspring: implication for pathogenesis of autism. Int J Dev Neurosc, i Vol. 23, No. 2-3, (April-May 2005), pp. 287-97, ISSN: 0736-5748

Modahl, C., Green, L. A., Fein, D., Morris, M., Waterhouse, L., Feinstein, C., \& Levin, H. (1998). Plasma oxytocin levels in autistic children. Biological psychiatry, Vol. 43, No. 4, (February 1998), pp. 270-277, ISSN: 0006-3223

Moretti, P., Sahoo, T., Hyland, K., Bottiglieri, T., Peters, S., del Gaudio, D., Roa, B., Curry, S., Zhu, H., Finnell, R. H., Neul, J. L., Ramaekers, V. T., Blau, N., Bacino, C. A., Miller, G., \& Scaglia, F. (2005). Cerebral folate deficiency with developmental delay, autism, and response to folinic acid. Neurology, Vol. 64, No. 6, (March 2005), pp. 1088-1090, ISSN: 0003-9942

Muhle, R., Trentacoste, S. V., \& Rapin, I. (2004). The Genetics of Autism. Pediatrics, Vol. 113, No. 5, (May 2004), pp. e472-486, ISSN: 00314005

Muscat, S. (2007). Influence of Food-Derived Maillard Reaction Products on the Cellular Response of Macrophages. Dissertation. Friedrich-Alexander-Universität ErlangenNürnberg, (March 2011), Available from http:// www.opus.ub.uni-erlangen.de/opus/volltexte/2007/604/

Nakamura, K., Sekine, Y., Ouchi, Y., Tsujii, M., Yoshikawa, E., Futatsubashi, M., Tsuchiya, K. J., Sugihara, G., Iwata, Y., Suzuki, K., Matsuzaki, H., Suda, S., Sugiyama, T., Takei, N., \& Mori, N. (2010). Brain Serotonin and Dopamine Transporter Bindings in Adults With High-Functioning Autism. Arch Gen Psychiatry, Vol. 67, No. 1, (January 2010), pp. 59-68, ISSN: 0003-990x

Nguyen, A., Rauch, T. A., Pfeifer, G. P., \& Hu, V. W. Global methylation profiling of lymphoblastoid cell lines reveals epigenetic contributions to autism spectrum disorders and a novel autism candidate gene, RORA, whose protein product is reduced in autistic brain. The FASEB Journal, Vol 24, No. 8, (August 2010), pp. 303651, ISSN: 0892-6638 
Oberman, L. M., Hubbard, E. M., McCleery, J. P., Altschuler, E. L., Ramachandran, V. S., \& Pineda, J. A. (2005). EEG evidence for mirror neuron dysfunction in autism spectrum disorders. Cog. Brain Res, Vol. 24, No. 2, (July 2005), pp. 190-198, ISSN: 0926-6410

Ohnishi, T., Matsuda, H., Hashimoto, T., Kunihiro, T., Nishikawa, M., Uema, T., \& Sasaki, M. 2000. Abnormal regional cerebral blood flow in childhood autism. Brain, Vol.123, No.9, (September 2000), pp.1838-1844, ISSN: 1838-1844

Page, L. A., Daly, E., Schmitz, N., Simmons, A., Toal, F., Deeley, Q., Ambery, F., McAlonan, G. M., Murphy, K. C., \& Murphy, D. G. M. (2006). In Vivo 1H-Magnetic Resonance Spectroscopy Study of Amygdala-Hippocampal and Parietal Regions in Autism. Am J Psychiatry, Vol. 163, No. 12, (December 2006), pp. 2189-2192, ISSN: 0002-953X

Paşca, S. P., Nemeş, B., Vlase, L., Gagyi, C. E., Dronca, E., Miu, A. C., \& Dronca, M. (2006). High levels of homoczsteine and low serum paraoxonase 1 arylesterase activity in children with autism. Life Sciences, Vol. 78, No. 19, (April 2006), pp. 2244-48, ISSN: 0024-3205

Perkins, T., Stokes, M., McGillivray, J., \& Bittar, R. (2010). Mirror neuron dysfunction in autism spectrum disorders. J Clin Neurosci, Vol. 17, No. 10, (October 2010), pp. 1239-1243, ISSN: 1532-2653

Perreau-Linck, E., Beauregard, M., Gravel, P., Paquette, V., Soucy, J. P., Diksic, M., \& Benkelfat, C. (2007). In vivo measurements of brain trapping of C-labelled alphamethyl-L-tryptophan during acute changes in mood states. J Psychiatry Neurosci., Vol. 32, No. 6, (November 2007), pp. 430-4, ISSN: 1180-4882

Pickering, M., Cumiskey, D., \& O'Connor, J. J. (2005). Actions of TNF-alpha on glutamatergic synaptic transmission in the central nervous system. Experimental Physiology, Vol. 90, No. 5, (September 2005), pp. 663-670, ISSN: 0958-0670

Pierce, K., Müller, R. A., Ambrose, J., Allen, G., \& Courchesne, E. (2001). Face processing occurs outside the fusiform "face area" in autism: evidence from functional MRI. Brain, Vol. 124, No. 10, (October 2001), pp. 2059-2073, ISSN: 0006-8950

Rizzolatti, G., \& Fabbri-Destro, M. (2010). Mirror neurons: from discovery to autism. Exp Brain Res, Vol. 200, No. 3-4, (January 2010), pp. 223-237, ISSN: 0014-4819

Rossignol, D. A., \& Rossignol L. W. (2006). Hyperbaric oxygen therapy may improve symptoms in autistic children. Med Hypotheses, Vol 67, No.2, (March 2006), pp. $216-$ 28, ISSN: 0306-9877

Saitoh, O., Karns, C. M., \& Courchesne, E. (2001). Development of the hippocampal formation from 2 to 42 years: MRI evidence of smaller area dentata in autism. Brain, Vol. 124, No. Pt 7, (July 2001), pp. 1317-1324, ISSN: 0006-8950

Sammarco, M. C., Ditch, S., Banerjee, A., \& Grabczyk, E. (2008). Ferritin L and H Subunits Are Differentially Regulated on a Post-transcriptional Level. Journal of Biological Chemistry, Vol. 283, No. 8, (February 2008), pp. 4578-4587, ISSN: 0021-9258

Sarachana, T, Xu, M, Wu, R. C., \& Hu, V. W. (2011). Sex hormones in autism: androgens and astrogens differentially and reciprocally regulate RORA, a novel candidate gene for autism. PLoS One, Vol 16, No. 2, (February 2011), pp. e17116, ISSN: 1932-6203

Schumann, C. M., \& Amaral, D. G. (2006). Stereological analysis of amygdala neuron number in autism. J Neurosci., Vol 26, No. 29, (July 2006), pp. 7674-7679, ISSN: 02706474 
Seyan, A. S., Hughes, R. D., \& Shawcross, D. L. (2010). Changing face of hepatic encephalopathy: role of inflammation and oxidative stress. World J Gastroenterol. Vol. 16, No. 27, (July 2010), pp. 3347-57, ISSN: 1007-9327

Singer, H. S., Morris, C. M., Williams, P. N., Yoon, D. Y., Hong, J. J., \& Zimmerman, A. W. (2006). Antibrain antibodies in children with autism and their unaffected siblings. $J$ Neuroimmunol, Vol. 178, No. 1, (December 2006), pp 149 -55, ISSN: 0165-5728

Smart, T. G., Hosie, A. M., \& Miller, P.S. (2004). Zn2+ Ions: Modulators of Excitatory and Inhibitory Synaptic Activity. The Neuroscientist, Vol. 10, No. 5, (October 2004), pp. 432-442, ISSN: 1073-8584

Smeltzer, M. D., Curtis, J. T., Aragona, B. J., \& Wang, Z. (2006). Dopamine, oxytocin, and vasopressin receptor binding in the medial prefrontal cortex of monogamous and promiscuous voles. Neuroscience Letters, Vol. 394, No. 2, (February 2006), pp. 146151, ISSN: 0304-3940

Stritch School of Medicine. (2009). Autism Candidate Gene Map (ACGMAP) Database, Accessed on 13.03.2011, Available from:

http://www.meddean.luc.edu/node/375

Stromswold, K. (2008). The Genetics of Speech and Language Impairments. NEJM, Vol. 359, No. 22, (November 2008), pp. 2381-83, ISSN: 0028-4793

Szewczyk, B., Poleszak, E., Pilc, A., \& Nowak, G. (2010). Ionic Glutamate Modulators in Depression (Zinc, Magnesium), In Glutamate-based Therapies for Psychiatric Disorders, Milestones in Drug Therapy, P. Skolnick (ed.), p. 21-38, Springer, Retrieved from: DOI 10.1007/978-3-0346-0241-9_2

Takeda, A., Hirate, M., Tamano, H., Nisibaba, D., \& Oku, N. (2003). Susceptibility to kainateinduced seizures under dietary zinc deficiency. Journal of Neurochemistry, Vol. 85, No. 6, (June 2003), pp. 1575-1580, ISSN: 1471-4159

Tsai, L. Y. (1999). Psychopharmacology in Autism. Psychosomatic Medicine Vol. 61, No. 5, (September 1999), pp.651-665, ISSN: 0033-3174

Verhoeven, J., De Cock, P., Lagae, L., \& Sunaert, S. Neuroimaging of autism. Neuroradiology, Vol. 52, No. 1, (January 2010), pp. 3-14, ISSN: 0028-3940

Wakasugi, K., Kitatsuji, C., \& Morishima, I. (2005). Possible neuroprotective mechanism of human neuroglobin. Ann N Y Acad Sci, Vol. 1053, (August 2005), pp. 220-230, ISSN: 0077-8923

Wang, Z. X., Liu, Y., Young, L. J., \& Insel, T. R. (2000). Hypothalamic vasopressin gene expression increases in both males and females postpartum in a biparental rodent. $J$ Neuroendocrinol., Vol. 12, No. 2, (February 2000), pp. 111-120, ISSN: 0953-8194

Waterlow, J. C. (2006). Protein turnover, CABI Publishing, ISBN: 0851996132, UK-USA.

Weiss, L. A., Shen, Y., Korn, J. M., Arking, D. E., Miller, D. T., Fossdal, R., Saemundsen, E., Stefansson, H., Ferreira, M. A. R., Green, T., Platt, O. S., Ruderfer, D. M., Walsh, C. A., Altshuler, D., Chakravarti, A., Tanzi, R. E., Stefansson, K., Santangelo, S. L., Gusella, J. F., Sklar, P., Wu, B.-L., \& Daly, M. J. (2008). Association between Microdeletion and Microduplication at 16p11.2 and Autism. NEJM, Vol. 358, No. 7, (February 2008), pp. 667-675, ISSN: 0028-4793

Weissman, J. R., Kelley, R. I., Bauman, M. L., Cohen, B. H., Murray, K. F., Mitchell, R. L., Kern, R. L., \& Natowicz, M. R. (2008). Mitochondrial disease in autism spectrum disorder patients: a cohort analysis. PLoS One, Vol. 3, No. 11, (December 2008), pp. e3815, ISSN: 1932-6203 
WHO Multicentre Growth Reference Study Group. (2007). WHO Child Growth Standards: Head circumference-for-age, arm circumference-for-age, triceps skinfold-for-age and subscapular skinfold-for-age: Methods and development. World Health Organization, ISBN-13: 9789241547185, Geneva, Retrived from http://www.who.int/childgrowth/standards/second_set/technical_report_2/en/ index.html

WHO. (2011). WHO Anthro (version 3.2.2, January 2011) and macros. Accesses on 2011-0205, Available from: http://www.who.int/childgrowth/software/en/

Willmore, L. J., Pickens IV, A., \& Pellok, J. M. (2006). Monitoring for Adverse Effects of Antiepileptic Drugs. In: The treatment of epilepsy: principles \& practice, Elaine Wyllie, Ajay Gupta, Deepak K. Lachhwani, pp. 735-747, Lippincott Williams \& Wilkins, ISBN: 9780781749954, Hardcover

Winslow, J., \& Insel, T. (1991). Social status in pairs of male squirrel monkeys determines the behavioral response to central oxytocin administration. J Neurosci., Vol. 11, No. 7. (July 1991), pp. 2032-2038, ISSN: 0270-6474

Winslow, J. T., Hastings, N., Carter, C. S., Harbaugh, C. R., \& Insel T. R. (1993). A role for central vasopressin in pair bonding in monogamous prairie voles. Nature, Vol. 365, No. 6446, (October 1993), pp. 545 - 548, ISSN: 0028-0836

Woods, J. S., Armel, S. E., Fulton, D. I., Allen, J., Wessels, K., Simmonds, P. L., Granpeesheh, D., Mumper, E., Bradstreet, J. J., Echeverria, D., Heyer, N. J., \& Rooney, J. P. K. (2010). Urinary Porphyrin Excretion in Neurotypical and Autistic Children. Environ Health Perspect. Vol. 118, No. 10, (October 2010), ISSN: 0091-6765

Xu, J., Zwaigenbaum, L., Szatmari, P., \& Scherer, S. W. (2004). Molecular Cytogenetics of Autism. Current Genomics Vol. 5, No. 4, (May 2004), pp. 347-364, ISSN: 1389-2029

Yamasaki, S., Yamasue, H., Abe, O., Suga, M., Yamada, H., Inoue, H., Kuwabara, H., Kawakubo, Y., Yahata, N., Aoki, S., Kano, Y., Kato, N., \& Kasai, K. (2010). Reduced Gray Matter Volume of Pars Opercularis Is Associated with Impaired Social Communication in High-Functioning Autism Spectrum Disorders. Biol Psychiatry, Vol 68, No. 12, (December 2010), pp. 1141-7, ISSN: 0006-3223

Yirmiya, N., Rosenberg, C., Levi, S., Salomon, S., Shulman, C., Nemanov, L., Dina, C., \& Ebstein, R. P. (2006). Association between the arginine vasopressin 1a receptor (AVPR1a) gene and autism in a family-based study: mediation by socialization skills. Mol Psychiatry, Vol. 11, No. 5, (May 2006), pp. 488-494, ISSN: 1359-4184

Yonan, A. L., Alarcon, M., Cheng, R., Magnusson, P. K., Spence, S. J., Palmer, A. A., Grunn, A., Juo, S. H., Terwilliger, J. D., Liu, J., Cantor, R. M., Geschwind, D. H., \& Gilliam, T. C. (2003). A genomewide screen of 345 families for autism-susceptibility loci. Am J Hum Genet, Vol. 73, No. 4, (October 2003), pp. 886-897, ISSN: 0002-9297

Yorbik, O., Sayal, A., Akay, C., Akbiyik, D. I., \& Sohmen, T. (2002). Investigation of antioxidant enzymes in children with autistic disorder. Prostaglandins, Leukotrienes and Essential Fatty Acids, Vol. 67, No. 5, (November 2002), pp. 341-343, ISSN: 09523278

Youdim, M.B. (2008). Brain iron deficiency and excess; cognitive impairment and neurodegeneration with involvement of striatum and hippocampus. Neurotox Res, Vol. 14, No. 1, (August 2008), pp. 45-56, ISSN: 1029-8428 
Zhang, Q., Ames, J. M., Smith, R. D., Baynes, J. W., \& Metz, T. O. (2009). A perspective on the Maillard reaction and the analysis of protein glycation by mass spectrometry: probing the pathogenesis of chronic disease. J Proteome Res, Vol. 8, No. 2, (February 2009), pp. 754-769, ISSN: 1535-3893

Zhao, B., \& Schwartz, J. P. (1998). Involvement of cytokines in normal CNS development and neurological diseases: recent progress and perspectives. J. Neurosci. Res. Vol. 52, No. 1, (April 1998), pp. 7-16, ISSN: 0360-4012

Zhao, L., \& Brinton, R. D. (2004). Suppression of Proinflammatory Cytokines Interleukin-1 $\beta$ and Tumor Necrosis Factor-a in Astrocytes by a V1 Vasopressin Receptor Agonist: A cAMP Response Element-Binding Protein-Dependent Mechanism. J Neurosci., Vol. 24, No. 9, (March 2004), pp. 2226-2235, ISSN: 0270-6474

Zilbovicius, M., Boddaert, N., Belin, P., Poline, J. B., Remy, P., Mangin, J.F., Thivard, L., Barthelemy, C., \& Samson, Y. (2000). Temporal lobe dysfunction in childhood autism: a PET study. Am J Psychiatry, Vol. 157, No. 12, (December 2000), pp.1988-93, ISSN: 0002-953X

Zilbovicius, M., Meresse, I., \& Boddaert, N. (2006). Autism: neuroimaging. Rev Bras Psiquiatr, Vol.28, Suppl 1, (May 2006), pp. S21-28, ISSN: 1516-4446 


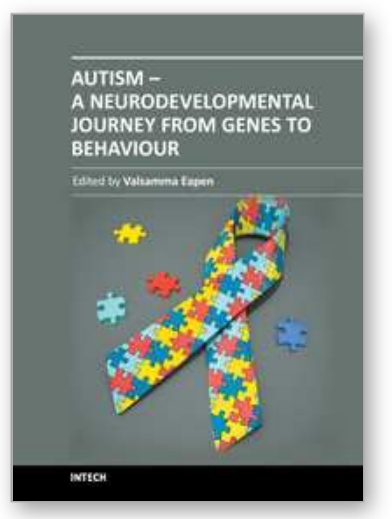

\author{
Autism - A Neurodevelopmental Journey from Genes to Behaviour \\ Edited by Dr. Valsamma Eapen
}

ISBN 978-953-307-493-1

Hard cover, 484 pages

Publisher InTech

Published online 17, August, 2011

Published in print edition August, 2011

The book covers some of the key research developments in autism and brings together the current state of evidence on the neurobiologic understanding of this intriguing disorder. The pathogenetic mechanisms are explored by contributors from diverse perspectives including genetics, neuroimaging, neuroanatomy, neurophysiology, neurochemistry, neuroimmunology, neuroendocrinology, functional organization of the brain and clinical applications from the role of diet to vaccines. It is hoped that understanding these interconnected neurobiological systems, the programming of which is genetically modulated during neurodevelopment and mediated through a range of neuropeptides and interacting neurotransmitter systems, would no doubt assist in developing interventions that accommodate the way the brains of individuals with autism function. In keeping with the multimodal and diverse origins of the disorder, a wide range of topics is covered and these include genetic underpinnings and environmental modulation leading to epigenetic changes in the aetiology; neural substrates, potential biomarkers and endophenotypes that underlie clinical characteristics; as well as neurochemical pathways and pathophysiological mechanisms that pave the way for therapeutic interventions.

\title{
How to reference
}

In order to correctly reference this scholarly work, feel free to copy and paste the following:

Michaela Dobre and Ileana Stoica (2011). Clinical Evaluations on the Diagnosis of Autism, Autism - A Neurodevelopmental Journey from Genes to Behaviour, Dr. Valsamma Eapen (Ed.), ISBN: 978-953-307-4931, InTech, Available from: http://www.intechopen.com/books/autism-a-neurodevelopmental-journey-fromgenes-to-behaviour/clinical-evaluations-on-the-diagnosis-of-autism

\section{INTECH}

open science | open minds

\section{InTech Europe}

University Campus STeP Ri

Slavka Krautzeka 83/A

51000 Rijeka, Croatia

Phone: +385 (51) 770447

Fax: +385 (51) 686166

www.intechopen.com

\section{InTech China}

Unit 405, Office Block, Hotel Equatorial Shanghai

No.65, Yan An Road (West), Shanghai, 200040, China 中国上海市延安西路65号上海国际贵都大饭店办公楼405单元

Phone: +86-21-62489820

Fax: +86-21-62489821 
(C) 2011 The Author(s). Licensee IntechOpen. This chapter is distributed under the terms of the Creative Commons Attribution-NonCommercialShareAlike-3.0 License, which permits use, distribution and reproduction for non-commercial purposes, provided the original is properly cited and derivative works building on this content are distributed under the same license. 